with the doctor-patient relationship, and progress must not be made at the expense of the integrity and welfare of existing patients. The standards must strike the right balance between optimal clinical research and careful clinical work. If they succeed they will benefit trial subjects, investigators, sponsors, regulators-and future patients.

Professor of Clinical Pharmacology,

EIGILL F HVIDBERG

University Hospital,

DK-2100 Copenhagen,

Denmark

\footnotetext{
1 Association of the British Pharmaceutical Industry. Guidelines on good clinical research practice. London: ABPI, 1988.

2 Kessler DA. The regulation of investigational drugs. N Engl f Med 1989;320:281-8.

3 Committee on Proprietary Medicinal Products, EEC. Recommended basis for the conduct of clinical trials of medicinal products in the European Community. Brussels: EEC (in press). (Document III/411/87.

4 Herxheimer A. The rights of the patient in clinical research. Lancet 1988;ii:1128-30.
}

\section{Epilepsy in women of childbearing age}

\section{If anticonvulsants cannot be avoided use carbamazepine}

Mothers who have epilepsy inevitably worry about the effect of the disease on their unborn babies. Questions about the impact of seizures on maternal and fetal health arise long before pregnancy occurs, and there is an increasing awareness of the teratogenic effect of anticonvulsant drugs. There is a genuine dilemma between controlling seizures and protecting the fetus from unnecessary exposure to anticonvulsant drugs. ${ }^{1}$ Unfortunately, some women are not told about the risk to the fetus and are not offered prenatal diagnosis. ${ }^{2}$

About one in 200 pregnancies is in a woman with epilepsy. ${ }^{3}$ Received wisdom suggests that pregnancy causes an increase in the fits, ${ }^{45}$ but this increase is largely caused by women not taking their drugs, losing sleep, and being given inadequate treatment. ${ }^{6}$ The pregnancy itself may have little influence on the pattern of attacks, and in a recent study there was no difference in the frequency of seizures before and during pregnancy. ${ }^{7}$ In general, women whose epilepsy is well controlled have few problems from their disease in pregnancy, and seizures increase in those whose attacks are poorly controlled at other times. In these circumstances generalised seizures are more hazardous than minor attacks: stillbirths have been recorded after a single generalised convulsion, ${ }^{8}$ and in a series of mothers with status epilepticus nine mothers and 14 infants died. ${ }^{9}$ Most of the complications of pregnancy are increased when the epilepsy is poorly controlled. ${ }^{910}$

Plasma concentrations of anticonvulsant drugs decrease during pregnancy. This does not commonly cause an increase in seizures, but when attacks do increase the plasma concentrations of the drugs are usually low. ${ }^{7}$ Reduction in blood concentration of anticonvulsant drugs may result from poor compliance ${ }^{6}$ increased metabolism of the drugs by hepatic enzymes, ${ }^{11}$ and a progressive reduction in albumin concentration, which may be associated with increased clearance of the unbound drug. ${ }^{12}$

Many different congenital malformations have been reported in children of epileptic mothers, and all anticonvulsant drugs have been incriminated as possible causes of the malformations. The most common abnormalities are orofacial clefts and congenital heart disease. ${ }^{13}$ Seventy abnormalities occur in every 1000 births to epileptic mothers, 2.4 times the rate in the general population. Abnormalities are more likely if anticonvulsant drugs are prescribed, ${ }^{13}$ if high concentrations of them are used, ${ }^{14}$ and if more than one is used. ${ }^{15}$ The first indication of a specific teratogenic effect resulting from anticonvulsant treatment was in 1982, when it was reported that nine out of 72 infants with neural tube defects in the Rhône Alps region of France had been exposed to valproic acid. ${ }^{16} \mathrm{~A}$ subsequent review of 2111 pregnancies showed a $1 \%$ risk of neural tube defects in infants exposed to valproic acid in utero ${ }^{17}-20$ times the rate in the general population.

Oakeshott and Hunt have recently reported three cases of spina bifida in infants born to women taking sodium valproate, none of whom were aware of the risk and none of whom were offered prenatal diagnosis. ${ }^{2}$ Their report emphasised the need for adequate counselling of pregnant women about the risks of anticonvulsant drugs, but of equal importance are the original choice of drug for girls with epilepsy, avoidance of polypharmacy, and regular review of the need for drug treatment. Although no anticonvulsant drug is free of risk, it seems prudent to avoid prescribing sodium valproate to girls unless there are specific indications such as generalised epilepsy with a combination of petit mal and major seizures. Petit mal alone is seldom a problem by the time pregnancy occurs, and thus even in the generalised epilepsies regular review is needed of the specific need for valproate.

The present consensus is that carbamazepine alone should be the first choice for a girl who requires an anticonvulsant drug. The need for continued treatment should then be reviewed after two years' remission. The results of the Medical Research Council's anticonvulsant withdrawal trial should provide more accurate information on relapse rates in the various groups, but in general any young woman free of seizures for two years should be offered the choice of withdrawing from anticonvulsant treatment.

There is much scope for improving the management of epilepsy in women of childbearing age. The greatest needs are better education of the women and their doctors and the recognition that in this particular group long term planning and good communication among the various caring agencies are of the utmost importance.

MICHAEL SAUNDERS

Consultant Neurologist,

Middlesbrough General Hospital,

Middlesbrough T\$5 5AZ

1 Yerby SM. Problems and management of the pregnant woman with epilepsy. Epilepsia 1987;28: $529-36$.

Oakeshott P, Hunt GM. Valproate and spina bifida. Br Med f 1989;298:1300-1.

3 Kalter H, Warkany J. Congenital malformations. N Engl F Med 1983;308:491-7.

4 Knight AH, Rhind EG. Epilepsy and pregnancy: a study of 153 pregnancies in 59 patients. Epilepsia 1975;16:99-110.

5 Philbert A, Dam M. The epileptic mother and her child. Epilepsia 1982;23:85-99.

6 Schmidt D, Conyen R, Avanzini G, et al. Change of seizure frequency in pregnant epileptic women. I Neurol Neurosurg Psychiatry 1983;46:751-5.

Gjerde IO, Strandjord RE, Ulstein $M$. The course of epilepsy during pregnancy: a study of 78 cases. Acta Neurol Scand 1988;78:198-205.

8 Higgins TA, Commerford JB. Epilepsy in pregnancy. Journal of the Irish Medical Association 1974;67:317-29.

9 Teramo K, Hiilesmaa VK. Pregnancy and foetal complications in epileptic pregnancies: a review of the literature. In: Janz D, Bossi L, Dam M, et al, eds. Epilepsy, pregnancy and the child. New York: Raven Press, 1982:53-9.

10 Yerby MS, Koepsell T, Daling J. Pregnancy complications and outcomes in a cohort of women with epilepsy. Epilepsia 1985;26:631-5.

$11 \mathrm{Nau} \mathrm{H}, \mathrm{Kunhz} \mathrm{H}$, Egger HJ, et al. Anticonvulsants during pregnancy and lactation: transplacental, maternal and neonatal pharmacokinetics. Clin Pharmacokinet 1981;7:508-43.

12 Yearby MS, Friel PN, Miller DQ. Carbamazepine protein binding and disposition in pregnancy. Ther Drug Monit 1985;7:269-73.

Ther Drug Monit 1985;7:269-73.
3 Fedrick J. Epilepsy and pregnancy: a report from the Oxford Record Linkage Study. Br Med $\mathcal{F}$ 1973;ii:442-8.

14 Danski LV, Andermann E, Andermann F, et al. Maternal epilepsy and congenital malformations: correlation with maternal anticonvulsant levels during pregnancy. In: Janz D, Bossi L, Dam M et al, eds. Epilepsy, pregnancy and the child. New York: Raven Press, 1982:251-8.

15 Lindhout D, Hoppener RJ, Meinardi $\mathrm{H}$. Teratogenicity of antiepileptic drug combinations with special emphasis on epoxidation of carbamazepine. Epilepsia 1984;25:77-83.

16 Valproic acid and spina bifida, preliminary report. MMWR 1982;31:565-6.

17 Lindhout D, Schmidt D. In-utero exposure to valproate and neural tube defects. Lance 1986;i:1392-3. 